\title{
Isolation and Characterization of Cell Wall Components of the Unicellular Cyanobacterium Synechococcus sp. PCC 6307
}

\author{
By DANIELA WOITZIK, JÜRGEN WECKESSER AND UWE J. JÜRGENS* \\ Institut für Biologie II, Mikrobiologie, der Albert-Ludwigs-Universität, Schänzlestr. 1, \\ D-7800 Freiburg i. Br., Federal Republic of Germany
}

(Received 2 July 1987; revised 23 October 1987)

\begin{abstract}
Cell walls and outer membranes, free of thylakoids and cytoplasmic membranes, were isolated from the unicellular cyanobacterium Synechococcus sp. PCC 6307. Electron microscopy revealed $\mathrm{C}$-shaped cell wall fragments, which were partially converted to outer membrane vesicles after removal of the peptidoglycan by lysozyme digestion. The major constituents of the outer membrane were proteins and lipopolysaccharide, while lipids and carotenoids were minor components. The polypeptide patterns of the outer membranes were dominated by two major proteins $\left(M_{\mathrm{r}} 52000\right.$ and 54000$)$. Five strongly polar lipids (unidentified), free fatty acids and small amounts of sulpholipid were detected in extracts of partially purified cell wall fractions, but monogalactosyldiglyceride and digalactosyldiglyceride were not found. The peptidoglycan layer ( $10 \mathrm{~nm}$ thick) was also isolated. Its chemical composition indicated an Al $\gamma$-type structure. The degree of cross-linkage was $57 \%$. A polysaccharide, consisting of fucose, mannose, galactose and glucose, was bound to the peptidoglycan, most likely via muramic acid 6phosphate.
\end{abstract}

\section{INTRODUCTION}

Cell walls of cyanobacteria are composed of a peptidoglycan layer and an outer membrane. Outer membrane constituents include proteins, lipids and carotenoids (Drews \& Weckesser, 1982; Resch \& Gibson, 1983; Omata \& Murata, 1984; Jürgens \& Weckesser, 1985; Benz \& Böhme, 1985). Lipopolysaccharides have been found in some, but not all, cyanobacteria studied (Weckesser et al., 1979; Schmidt et al., $1980 a, b$; Raziuddin et al., 1983). Proteins of apparent $M_{\mathrm{r}}$ 50000 to 70000 dominate the polypeptide patterns of cell walls from Synechocystis sp. PCC 6714 (Omata \& Murata, 1984; Jürgens et al., 1985), Anacystis nidulans (Golecki, 1977; Murata et al., 1981; Resch \& Gibson, 1983), Synechococcus leopoliensis and Synechococcus sp. (Resch \& Gibson, 1983). The two major outer membrane proteins of Synechocystis sp. PCC 6714 are associated with peptidoglycan by strong ionic interactions (Jürgens et al., 1985). Carotenoids and lipids are minor, but regular constituents of the outer membrane of Synechocystis sp. (Jürgens \& Weckesser, 1985) and Synechococcus sp. (Murata et al., 1981; Resch \& Gibson, 1983). The peptidoglycan of Synechocystis sp. PCC 6714 has properties in common with that of Gram-positive bacteria (Jürgens et al., 1983, 1985).

This paper describes the isolation and chemical characterization of the cell wall, the outer membrane and the peptidoglycan of the cyanobacterium Synechococcus sp. PCC 6307, the reference strain for the high GC group (Rippka et al., 1979).

\footnotetext{
Abbreviations: $\mathrm{A}_{2} \mathrm{pm}$, diaminopimelic acid; GlcNAc, $N$-acetylglucosamine; GlcN-6-P, glucosamine 6-phosphate; ManNAc, $N$-acetylmannosamine; MurNAc, $N$-acetylmuramic acid; MurN-6-P, muramic acid 6-phosphate; Tyv, Tyvelose.
} 


\section{METHODS}

Strain and growth conditions. Synechococcus sp. PCC 6307, obtained from the Pasteur Culture Collection (PCC), Paris, France, was grown photoautotrophically in BG-11 medium pH 7.5 (Rippka et al., 1979) at $25^{\circ} \mathrm{C}$, illuminated with white fluorescent lamps $(5000 \mathrm{~lx})$. Mass cultures $(10 \mathrm{l})$ were prepared in a Biostat $\mathrm{E}$ fermenter (Braun Melsungen) gassed continuously with air $/ \mathrm{CO}_{2}\left(99: 1, \mathrm{v} / \mathrm{v}\right.$, at $\left.2501 \mathrm{~h}^{-1}\right)$. Cells were harvested in the stationary growth phase by centrifugation $(12000 \mathrm{~g}, 30 \mathrm{~min})$, washed once with $20 \mathrm{mM}$-Tris/ $\mathrm{HCl}$ buffer, $\mathrm{pH} 8.0$ ('Tris-buffer', used throughout this study) and stored at $-20^{\circ} \mathrm{C}$ until use.

Isolation of cell walls. Cells were broken in Tris-buffer by means of a cooled $\left(4{ }^{\circ} \mathrm{C}\right.$ ) vibrogen shaker (type Vi $2 ; \mathrm{E}$. Bühler) for $20 \mathrm{~min}$ at full speed using a ratio of cells to glass beads $(0 \cdot 17-0 \cdot 18 \mathrm{~mm}$ in diameter) of $1: 2(\mathrm{w} / \mathrm{w})$. The cell homogenate was passed through a glass filter (type G-1; Schott) to remove glass beads. Whole cells were separated by low-speed centrifugation $(300 \mathrm{~g}, 10 \mathrm{~min})$. Cell envelopes were obtained from the supernatant after centrifugation at $12000 \mathrm{~g}$ for $30 \mathrm{~min}$. They were washed with Tris-buffer until the final supernatant was colourless. The cell envelope fraction ( $5 \mathrm{ml}$ suspension, $2 \mathrm{mg}$ protein $\mathrm{ml}^{-1}$ ) was loaded onto a discontinuous sucrose gradient $[10 \mathrm{ml}$ each of 55,50 and $40 \%(\mathrm{w} / \mathrm{w})$ sucrose and $5 \mathrm{ml}$ of $30 \%(\mathrm{w} / \mathrm{w})$ sucrose in Tris-buffer] and centrifuged in a swing-out bucket rotor (AS 4.13, Kontron) for $12 \mathrm{~h}$ at $16000 \mathrm{~g}$. Cell walls were isolated from the $55 \%$ sucrose band and washed free of sucrose by resuspension in Tris-buffer and centrifugation $(48000 \mathrm{~g}, 30 \mathrm{~min})$. Sucrose gradient centrifugation was repeated twice, yielding the gradient-purified cell wall fraction ' $\mathrm{CW}$ I' as the final pellet. For further purification the $\mathrm{CW}$ I fraction was resuspended in $5 \mathrm{ml}$ Tris-buffer containing $10 \mathrm{~mm}-\mathrm{MgCl}_{2}$. After the addition of the same volume of $4 \%(w / w)$ Triton X-100 in Tris-buffer, Triton-soluble components were extracted from the cell walls by stirring for $20 \mathrm{~min}$ at $23^{\circ} \mathrm{C}$ (Schnaitman, 1971). Cell walls were recovered by centrifugation $(48000 \mathrm{~g}, 30 \mathrm{~min})$ and washed several times with Tris-buffer containing $10 \mathrm{mM}-\mathrm{MgCl}_{2}$ until the supernatant was free of detergent (lack of absorbance at $280 \mathrm{~nm}$; Garewal, 1973). The final pellet contained the Triton-insoluble cell wall fraction ' $\mathrm{CW}$ II'.

Isolation of outer membranes. The $\mathrm{CW}$ I or $\mathrm{CW}$ II fraction was resuspended in $20 \mathrm{~mm}$-ammonium acetate buffer, pH 6.5, and digested with lysozyme [from hen egg white, 53000 units (mg protein) ${ }^{-1}$, Sigma] in an enzyme/substrate ratio of $1: 25(\mathrm{w} / \mathrm{w})$ at $37^{\circ} \mathrm{C}$ for $24 \mathrm{~h}$. Outer membranes (OM I and OM II, respectively) were collected by centrifugation $(48000 \mathrm{~g}, 1 \mathrm{~h}$ ) and were further purified by sucrose gradient centrifugation (as given above). Sucrose was removed by repeated centrifugation $(48000 \mathrm{~g}, 1 \mathrm{~h})$ and resuspension in Tris-buffer containing $10 \mathrm{mM}-\mathrm{MgCl}_{2}$.

Isolation of peptidoglycan. Gradient-purified cell walls (fraction CW I, $1 \mathrm{~g}$ wet weight, see above) were suspended in 4-5 $\mathrm{ml}$ water and added dropwise into $50 \mathrm{ml}$ of a boiling $4 \%(\mathrm{w} / \mathrm{v})$ SDS solution containing $0 \cdot 1 \% 2$ mercaptoethanol. After heating to $100^{\circ} \mathrm{C}$ for $15 \mathrm{~min}$ and centrifugation $\left(48000 \mathrm{~g}, 15^{\circ} \mathrm{C}, 1 \mathrm{~h}\right)$, the extraction was repeated with the sediment (the supernatant was discarded). The final sediment ('rigid layer') was washed with distilled water for a complete removal of SDS (Braun \& Rehn, 1969; Jürgens et al., 1983). Protein was removed from the rigid layer by incubation with pronase [from Streptomyces griseus, specific activity 8 units (mg protein) ${ }^{-1}$; 40 units per $\mathrm{mg}$ rigid layer protein were used] while stirring at $37^{\circ} \mathrm{C}$ for $24 \mathrm{~h}$. After centrifugation at $48000 \mathrm{~g}$ $\left(15^{\circ} \mathrm{C}, 20 \mathrm{~min}\right.$ ), the sediment (peptidoglycan-polysaccharide complex) was boiled in $4 \%$ (w/v) SDS for $15 \mathrm{~min}$ and subsequently freed from SDS by washing with distilled water. For hydrofluoric acid (HF) treatment, $20 \mathrm{mg}$ peptidoglycan-polysaccharide complex was suspended in $2 \mathrm{ml}$ ice-cold $\mathrm{HF}$ and incubated at $0{ }^{\circ} \mathrm{C}$ for $48 \mathrm{~h}$. Peptidoglycan was then sedimented at $12000 \mathrm{~g}\left(4^{\circ} \mathrm{C}, 15 \mathrm{~min}\right)$, washed several times with ice-cold distilled water and lyophilized.

Isolation and separation of lipids and carotenoids. Lipids and carotenoids were extracted from cell wall and outer membrane fractions with trichloromethane/methanol $(1: 1, \mathrm{v} / \mathrm{v})$ under dim light (Bligh \& Dyer, 1959). Phase separation was achieved by the addition of $2.5 \mathrm{vols}$ trichloromethane and $1 \%(\mathrm{w} / \mathrm{w}) \mathrm{NaCl}$ followed by centrifugation $(7000 \mathrm{~g}, 5 \mathrm{~min})$. The methanol/water phase was re-extracted four times with an equal volume of trichloromethane. The trichloromethane phases containing lipids and carotenoids were combined and evaporated to a final volume of $0.25-0.5 \mathrm{ml}$ and stored in sealed tubes under a nitrogen atmosphere at $-20{ }^{\circ} \mathrm{C}$. Lipids and carotenoids were separated as described previously (Jürgens et al., 1985).

Electron microscopy and SDS-PAGE. Embedding and ultrathin sectioning techniques were as described by Golecki (1977). SDS-PAGE was performed as cited by Jürgens \& Weckesser (1985), using 15\% (w/v) polyacrylamide slab gels.

Analytical chemical methods. Amino acids and amino sugars were determined after hydrolysis with $4 \mathrm{M}-\mathrm{HCl}$ $\left(105^{\circ} \mathrm{C}, 18 \mathrm{~h}\right)$ in an automatic amino acid analyser, model LC 6001 (Biotronik). Neutral sugars were liberated by treatment with $0.1 \mathrm{M}-\mathrm{HCl}\left(100^{\circ} \mathrm{C}, 48 \mathrm{~h}\right)$ and quantified by gas-liquid chromatography (GLC) as their alditol acetates using a Varian Aerograph (Varian, model 1440) and a glass column (length $150 \mathrm{~cm}$, internal diameter $3 \mathrm{~mm} ; 3 \%$ ECNSS-M on Gas-chrom Q, $100-200$ mesh; isothermal column temperature $180{ }^{\circ} \mathrm{C}$; injector and detector temperature $240^{\circ} \mathrm{C}$ ). Fatty acids were quantified after methyl-esterification in methanol/concentrated $\mathrm{HCl}(5: 1, \mathrm{v} / \mathrm{v})$ at $85^{\circ} \mathrm{C}$ for $18 \mathrm{~h}$ and determined by GLC on a glass column (15\% EGSS-X on Gas-chrom P, 100 200 mesh; column size and temperatures as for the estimation of neutral sugar derivatives, see above). Organic 
phosphorus was determined by the method of Lowry et al. (1954). The purity of the cell wall and outer membrane fractions was confirmed by measuring the degree of chlorophyll $a$ contamination, using the methods of extraction and determination described by Mackinney (1941).

\section{RESULTS}

\section{Fine structure of the cell wall}

Gradient-purified and Triton-insoluble cell wall fractions (CW I and CW II, respectively) appeared as $\mathrm{C}$-shaped fragments in ultrathin sections, showing an electron-dense peptidoglycan layer (10 nm thick) and a double-track-structured outer membrane ( $8 \mathrm{~nm}$ thick) (Fig. 1a). In ultrathin sections of outer membrane preparations the peptidoglycan layer was not detectable, demonstrating the efficient digestion of this layer by lysozyme. Furthermore, the $\mathrm{C}$-shaped cell wall fragments were partially converted into outer membrane vesicles after the lysozyme treatment (Fig. $1 b$ ).

\section{Chemical composition of the cell wall and outer membrane}

As evidenced by the chemical composition (Table 1) of unfractionated preparations, cell walls of Synechococcus sp. PCC 6307 contained proteins, lipopolysaccharide, polysaccharide, lipids and carotenoids as well as the peptidoglycan-specific components MurNAc and $\mathrm{A}_{2} \mathrm{pm}$. The fatty acids $\beta-\mathrm{C}_{14} \mathrm{OH}$ and $\beta-\mathrm{C}_{16} \mathrm{OH}$, the amino sugars GlcN and $\mathrm{ManN}$, and the neutral sugars Rha, Fuc, Man, Gal, Glc and Tyv were constituents of the lipopolysaccharide (Schmidt et al., $1980 a$ ). Part of the GlcNAc, ManNAc and Man comprised components of the peptidoglycanbound polysaccharide (see below). Fatty acids other than the $\beta$-hydroxy fatty acids are representative of lipids of the outer membrane other than those contained in the lipopolysaccharide. Some loss of lipopolysaccharide and lipids was observed after Triton X-100
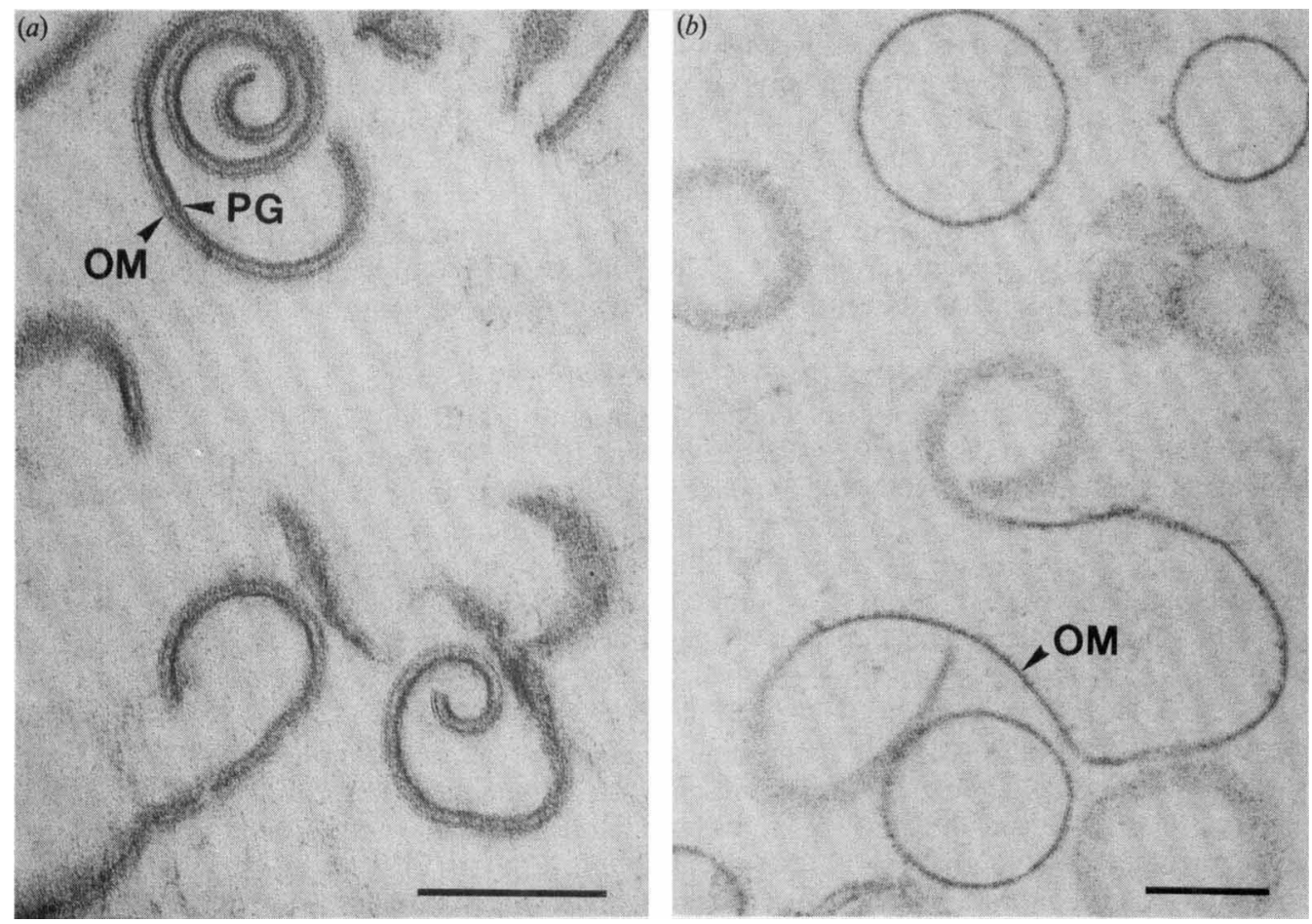

Fig. 1. Ultrathin sections of gradient-purified cell walls CW I $(a)$ and outer membranes OM II $(b)$ from Synechococcus sp. PCC 6307. Bars, $0 \cdot 2 \mu \mathrm{m}$. For terminology of CW I and OM II see Methods. PG, peptidoglycan; OM, outer membrane. 
Table 1. Chemical composition of gradient-purified cell walls $(C W I)$, of Triton-insoluble cell walls (CW In), and of outer membranes (OM II) from Synechococcus sp. PCC 6307

\begin{tabular}{|c|c|c|c|}
\hline \multirow[b]{2}{*}{ Compound } & \multicolumn{3}{|c|}{ Content (nmol per mg fraction dry weight)* } \\
\hline & $\mathrm{CW} \mathrm{I}$ & CW II & OM II \\
\hline Glu & 377 & 383 & 229 \\
\hline Ala & 537 & 558 & 353 \\
\hline $\mathrm{A}_{2} \mathrm{pm}$ & 178 & 197 & 17 \\
\hline Other amino acids & 1834 & 1850 & 2574 \\
\hline GlcNAc & 352 & 336 & 122 \\
\hline MurNAc & 124 & 134 & 6 \\
\hline ManNAc & 101 & 95 & 41 \\
\hline Rha & 257 & 290 & 627 \\
\hline Fuc & 78 & 70 & 189 \\
\hline Man & 88 & 126 & 111 \\
\hline Gal & 63 & 39 & 133 \\
\hline Glc & 42 & 34 & 67 \\
\hline Tyv & + & + & + \\
\hline Phosphate & + & + & + \\
\hline $\mathrm{C}_{14: 0}$ & 26 & 2 & 3 \\
\hline $\mathrm{C}_{16: 0}$ & 122 & 30 & 27 \\
\hline $\mathrm{C}_{16: 1}$ & 11 & 3 & 3 \\
\hline$C_{18: 0}$ & 11 & 1 & 2 \\
\hline $\mathrm{C}_{18: 1}$ & 18 & 3 & 5 \\
\hline $\mathrm{C}_{14} \mathrm{OH}$ & 80 & 27 & 28 \\
\hline $\mathrm{C}_{16} \mathrm{OH}$ & 64 & 40 & 47 \\
\hline Unknown fatty acids & 184 & 39 & 46 \\
\hline Carotenoids & + & + & + \\
\hline
\end{tabular}

extraction of gradient-purified cell walls, as indicated by a decrease of the fatty acid contents (Table 1). Carotenoids were detected in cell wall (CW I and CW II) and outer membrane (OM II) fractions (amounts below $1 \%$ of fraction dry weight). The purified outer membrane fraction (OM II, Table 1) contained very few peptidoglycan components, due to efficient removal of the peptidoglycan by lysozyme digestion. Furthermore, the recovery of constituents of the peptidoglycan-bound polysaccharide (see below) in the supernatant of lysozyme-treated cell walls (after centrifugation at $176000 \mathrm{~g}, 4{ }^{\circ} \mathrm{C}, 1 \mathrm{~h}$ ) indicated that this enzymic digestion not only removed the peptidoglycan but also its specific polysaccharide (data not shown).

\section{Outer membrane proteins}

The polypeptide patterns of cell envelopes, gradient-purified cell walls (CW I), and Tritoninsoluble cell walls (CW II) of Synechococcus sp. PCC 6307 were dominated by two outer membrane proteins of $M_{\mathrm{r}} 52000$ and 54000 (Fig. 2, lanes B, C and D, respectively). A few other proteins were present in only minor quantities. Purified outer membrane fractions OM I and OM II (Fig. 2, lanes E and F, respectively) showed protein patterns identical to those of the corresponding cell wall fractions CW I and CW II, but were enriched in a high- $M_{\mathrm{r}}$ protein $\left(M_{\mathrm{r}}\right.$ 97000 ) and allowed the detection of a protein of $M_{\mathrm{r}} 37000$, not visible prior to purification.

\section{Outer membrane carotenoids}

Cell walls and purified outer membrane fractions of Synechococcus sp. PCC 6307 were intensely yellow coloured due to the presence of carotenoids. Absorption spectra showed maxima at 443, 462, and $491 \mathrm{~nm}$ (Fig. 3). At least four carotenoids (not identified) were detected in pigment extracts of the Triton-insoluble fraction, CW-II (Fig. $4 b$ ) and in purified outer membranes, OM-II (data not shown). Two carotenoids (Fig. $4 b$, bands 3 and 4) dominated the pigment pattern. Echinenone and $\beta$-carotene, carotenoids indicative of the thylakoid/cytoplasmic membrane fraction (Jürgens \& Weckesser, 1985), were absent from CW II and OM-II fractions. Chlorophyll $a$, a typical component of the cyanobacterial thylakoid membrane, was 


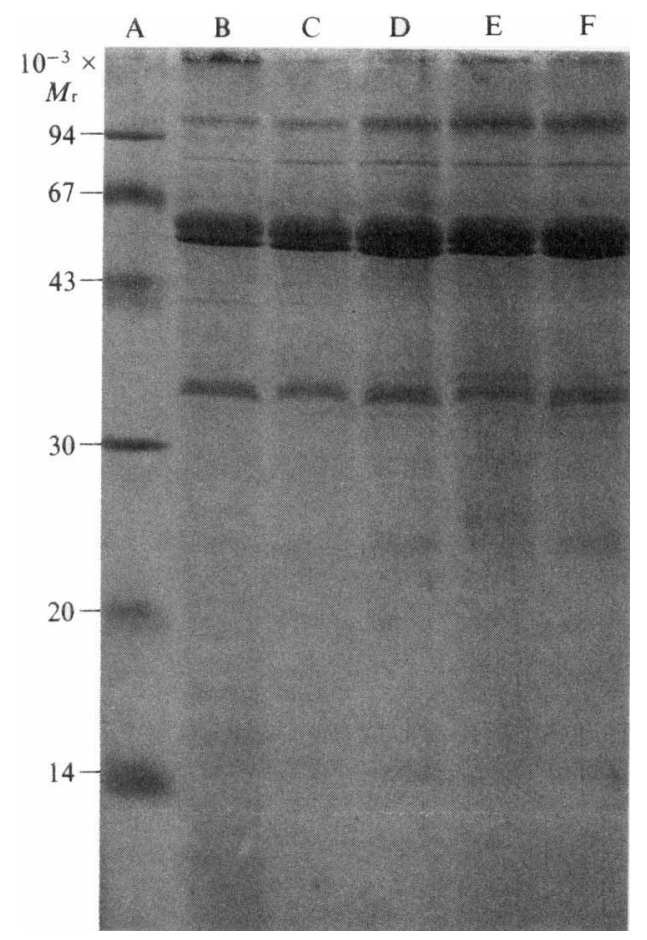

Fig. 2. Polypeptide patterns of cell envelopes (B), gradient-purified cell walls (C), Triton-insoluble cell walls (D), and outer membrane fractions OM I (E) and OM II (F). Lane A contains standard proteins. Samples containing $30 \mu \mathrm{g}$ protein were boiled in SDS-PAGE buffer for $5 \mathrm{~min}$ and subjected to electrophoresis in a $15 \%$ polyacrylamide slab gel, at a constant current of $10 \mathrm{~mA}$. For details on respective fractions see Methods.

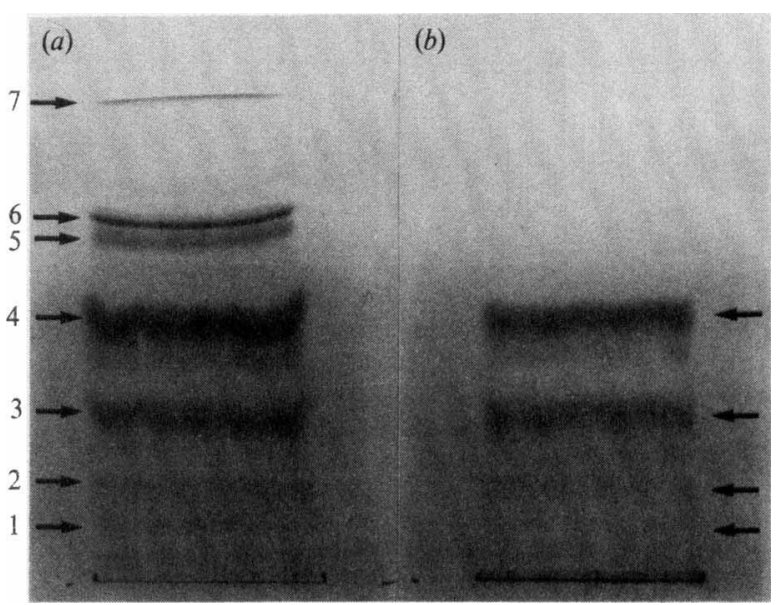

Fig. 4

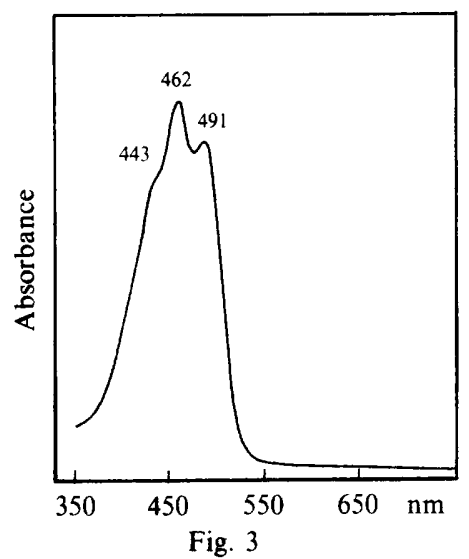

Fig. 3. Absorption spectrum of the pigment extract of the Triton-insoluble cell wall fraction (CW II) in trichloromethane, recorded at room temperature.

Fig. 4. Thin-layer chromatography of pigment extracts from CW I ( $a$ ) and CW II (b) fractions on silica aluminium foils $(5 \times 10 \mathrm{~cm}$ ). The solvent system (Stransky \& Hager, 1970) was light petroleum (b.p. 40$\left.60^{\circ} \mathrm{C}\right) / 2$-propanol/water $(100: 11: 0 \cdot 5$, by vol.). Pigments: $1-4$, unknown carotenoids $; 5$, echinenone; 6 , chlorophyll $a ; 7, \beta$-carotene. 

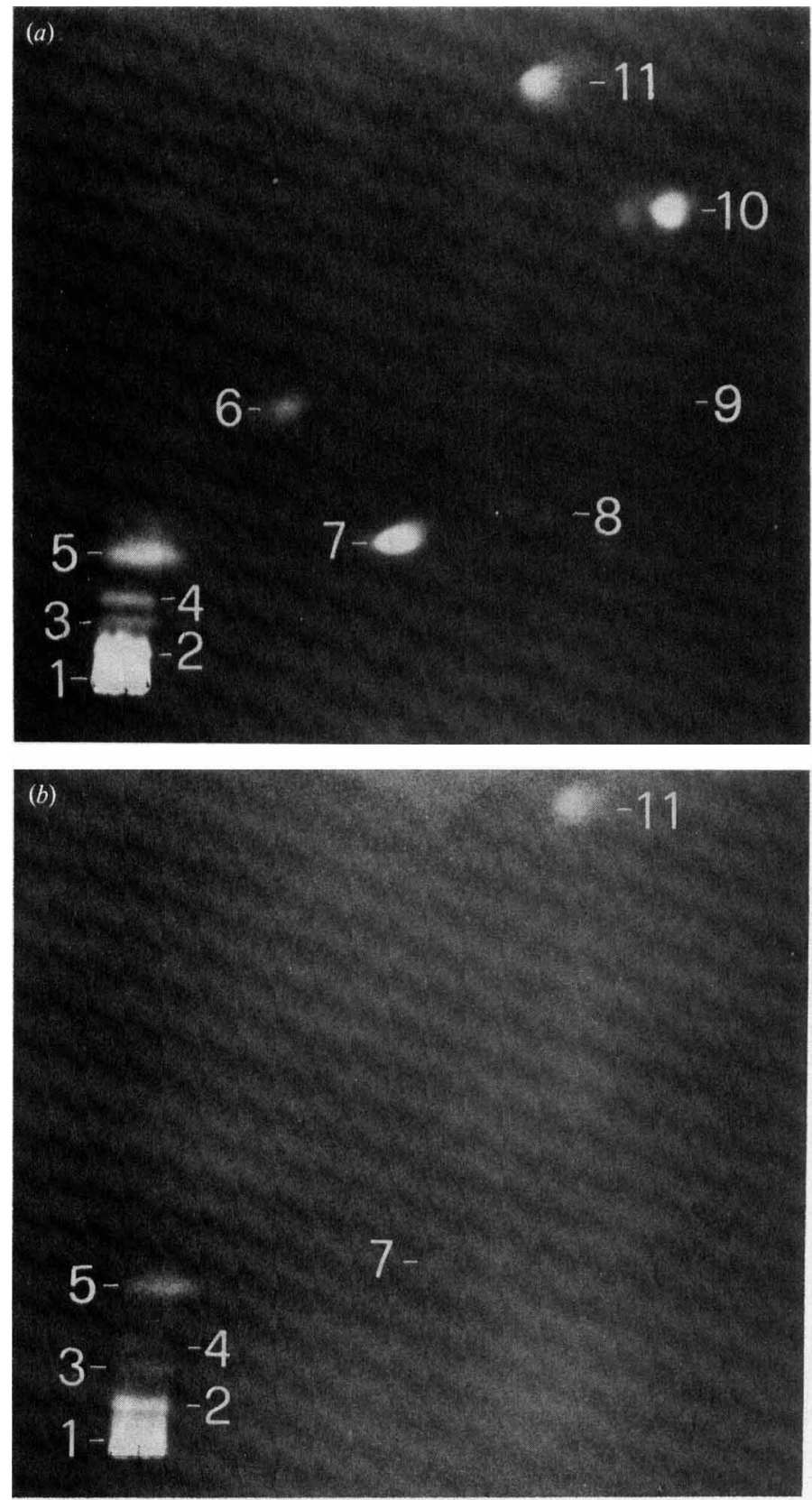

Fig. 5. Separation of lipid extracts from the gradient-purified (CW I) and the Triton-insoluble (CW II) cell wall fractions by two-dimensional thin-layer chromatography (separation and detection were as described by Jürgens et al., 1985). Lipids: 1-5, unknown polar lipids; 6 , digalactosyldiglyceride; 7, sulpholipid; 8, phosphatidylglycerol; 9, unknown lipid; 10, monogalactosyldiglyceride; 11, free fatty acids.

also absent, as confirmed by thin-layer chromatography and spectrophotometric analysis. In contrast, fraction CW I, not Triton purified, contained in addition to carotenoids 1-4, small amounts of echinenone, chlorophyll $a$ and $\beta$-carotene (Fig. $4 a$, bands 5, 6, and 7, respectively), due to some contamination by thylakoid membranes, and possibly also by cytoplasmic membranes. 
Table 2. Chemical composition of the rigid layer (SDS-insoluble cell wall fraction), of the peptidoglycan-polysaccharide complex, and of the isolated peptidoglycan of Synechococcus sp. PCC 6307

\begin{tabular}{|c|c|c|c|}
\hline \multirow[b]{2}{*}{ Compound } & \multicolumn{3}{|c|}{ Content (nmol per mg fraction dry weight) ${ }^{*}$} \\
\hline & Rigid layer & $\begin{array}{l}\text { Peptidoglycan- } \\
\text { polysaccharide } \\
\text { complex }\end{array}$ & Peptidoglycan \\
\hline Glu & 567 & 674 & 677 \\
\hline Ala & 908 & 1037 & 906 \\
\hline $\mathrm{A}_{2} \mathrm{pm}$ & 507 & 620 & 753 \\
\hline Gly & 83 & 6 & 7 \\
\hline Compound $\mathrm{X} \dagger$ & 57 & 42 & 32 \\
\hline Other amino acids & 340 & - & - \\
\hline GlcNAc & 982 & 935 & 786 \\
\hline MurNAc & 465 & 558 & 559 \\
\hline MurN-6-P & + & + & - \\
\hline ManNAc & 220 & 128 & 40 \\
\hline Fuc & 14 & 22 & 18 \\
\hline Man & 321 & 182 & 72 \\
\hline Gal & 7 & 12 & 11 \\
\hline Glc & 11 & 8 & 16 \\
\hline Phosphate & 8 & 11 & - \\
\hline
\end{tabular}

\section{Outer membrane lipids}

The Triton-insoluble cell wall fraction CW II, but not the CW I preparation, lacked monogalactosyldiglyceride and digalactosyldiglyceride, galactolipids typical of thylakoid membranes; this clearly demonstrates the value of the Triton purification step (Fig. 5). Five unidentified strongly polar lipids, free fatty acids, and small amounts of sulpholipid were detected in the CW II fraction. One of the polar lipids (spot 5 in Fig. 5) seemed to be a unique constituent of the cell wall since it was absent from cytoplasmic/thylakoid membrane fractions (data not shown).

\section{'Rigid layer' and peptidoglycan}

The rigid layer (SDS-insoluble cell wall fraction) was obtained in a $43 \%$ yield (net weight basis) from $\mathrm{CW}$ I and $\mathrm{CW}$ II preparations. It was enriched in the peptidoglycan-specific components MurNAc and $\mathrm{A}_{2}$ pm, and contained amino acids and neutral sugars (Table 2). Pronase treatment of the rigid layer fraction (and removal of the enzyme by SDS) yielded the peptidoglycan-polysaccharide complex. The peptidoglycan constituents $\mathrm{A}_{2} \mathrm{pm}$, MurNAc, GlcNAc, Ala and Glu were found in a molar ratio of $1 \cdot 0: 0 \cdot 9: 1 \cdot 5: 1 \cdot 7: 1 \cdot 1$ (Table 2). In addition, MurN-6-P was identified on the amino acid analyser; GlcN-6-P was absent. The fraction contained non-peptidoglycan compounds such as neutral sugars, Fuc, Man, Gal and Glc. Fatty acids were not found. MurN-6-P was confirmed by two-dimensional thin-layer electrophoresis/chromatography separation of a partial acid hydrolysate $\left(4 \mathrm{M}-\mathrm{HCl}, 100^{\circ} \mathrm{C}, 30 \mathrm{~min}\right)$ of the complex. The residual peptide pattern was essentially identical to that of Synechocystis sp. PCC 6714 (Jürgens et al., 1983). The peptidoglycan-polysaccharide complex was treated with $48 \%$ aqueous $\mathrm{HF}$ in the cold in order to cleave possible phosphodiester bonds at MurN-6-P between peptidoglycan and polysaccharide. The peptidoglycan fraction, recovered in the pellet after centrifugation at $12000 \mathrm{~g}$, amounted to a $66 \%$ yield (dry weight basis). The peptidoglycan constituents were confirmed in the expected molar ratios (Table 2). Neutral sugars and phosphate were not completely removed (indicating incomplete separation), but their contents had decreased significantly and MurN-6-P was no longer detectable by two-dimensional thinlayer electrophoresis/chromatography of partial acid hydrolysates (experimental conditions as for the peptidoglycan-polysaccharide complex). 


\section{DISCUSSION}

Cell walls and outer membranes of Synechococcus sp. PCC 6307 were isolated free of cytoplasmic and thylakoid membranes as shown by electron microscopy, SDS-PAGE and comparison of pigment and lipid patterns. The intense yellow colour of cell walls was due to the presence of carotenoids localized in the outer membrane as described for Synechocystis sp. PCC 6714 (Jürgens \& Weckesser, 1985). The stability of cell walls against non-ionic detergents was as high, as with other unicellular cyanobacteria (Resch \& Gibson, 1983; Jürgens et al., 1985). The polypeptide patterns of the gradient-purified and Triton X-100-insoluble cell walls were very similar. Thus, proteins were not removed from the outer membrane by the detergent. Similar observations have been made with Escherichia coli (Schnaitman, 1971). However, as shown for $E$. coli (Schnaitman, 1971), Triton X-100 extraction partially removed lipids and some lipopolysaccharide, although such loss should in principle be prevented by stabilization of the outer membrane by the addition of magnesium chloride. The sugar spectrum of the outer membrane of Synechococcus included typical O-specific sugars of the isolated lipopolysaccharide, such as tyvelose or rhamnose (Schmidt et al., 1980a; Weckesser et al., 1979). These sugars (and consequently the lipopolysaccharide) were removed by extraction of the cell wall with $\operatorname{SDS}\left(2 \%, \mathrm{w} / \mathrm{v}, 90^{\circ} \mathrm{C}, 5 \mathrm{~min}\right)$. It should be noted that SDS extraction at lower temperature did not remove the lipopolysaccharide. The phosphorus content of the outer membrane of Synechococcus sp. PCC 6307, although relatively low, and the abundance of strongly polar lipids, suggests the presence of phospholipids as well as glycolipids other than monogalactosyldiglyceride and digalactosyldiglyceride. A peptidoglycan-protein-polysaccharide complex was obtained from the rigid layer (SDS-insoluble cell wall fraction). The sugar spectrum found in this fraction (Fuc, Man, Gal, ManNAc, GlcNAc; the GlcNAc to be ascribed partly to the peptidoglycan) was different from that of the lipopolysaccharide of Synechococcus sp. PCC 6307 (Schmidt et al., 1980a). Fatty acids and also the neutral sugars rhamnose and tyvelose, characteristic of the lipopolysaccharide of this strain, were lacking in the peptidoglycanpolysaccharide complex. A different composition of the lipopolysaccharide compared to that of the polysaccharide bound to the peptidoglycan has also been observed in cell walls of Synechocystis sp. PCC 6714 (Jürgens et al., 1985; Jürgens \& Weckesser, 1986).

The peptidoglycan of Synechocystis sp. PCC 6714 (Jürgens et al., 1983) is of the Aly type according to the classification by Schleifer \& Kandler (1972). The comparable chemical composition of the peptidoglycan of Synechococcus sp. PCC 6307 suggests a similar structure. In both these cyanobacteria, the degree of cross-linkage is in the range of that determined for the peptidoglycans of Gram-positive bacteria. Another similarity to Gram-positive bacteria is that the polysaccharide of the peptidoglycan-polysaccharide complex of Synechococcus sp. PCC 6307 is most probably bound via phosphodiester bridges to MurN of the peptidoglycan. (Insufficient separation of the polysaccharide from the peptidoglycan observed after $\mathrm{HF}$ treatment might have two explanations: either incomplete cleavage during HF treatment or co-sedimentation of the polysaccharide with peptidoglycan due to a higher polymeric structure of the polysaccharide. The lack of MurN-6-P in the peptidoglycan fraction favours the latter explanation.) Fragments confirming the binding mechanism proposed above were recently identified with Synechocystis sp. PCC 6714 (Jürgens \& Weckesser, 1986).

It is concluded that the genetically only distantly related cyanobacteria, Synechococcus sp. PCC 6307 and Synechocystis sp. PCC 6714 share common characteristics with respect to cell wall structure. Both strains synthesize a lipopolysaccharide-containing outer membrane and a relatively thick (10-12 nm) peptidoglycan layer. The latter is composed of about eight single layers (Jürgens et al., 1985) and is complexed to a specific polysaccharide. Peptidoglycans of this type are characteristic of Gram-positive bacteria; however, these bacteria also contain teichoic acids, not encountered in the peptidoglycan-polysaccharide complex of Synechocystis sp. PCC 6714 (Jürgens \& Weckesser, 1986) and Synechococcus sp. PCC 6307. These observations support the theory (Jürgens et al., 1983: Jürgens \& Weckesser, 1986) that cyanobacteria might have developed a unique cell wall organization combining structural elements typical of both Gram-negative and Gram-positive bacteria. However, representatives of other genera will have to be studied to prove the generality of this proposal. 
The authors gratefully acknowledge J. R. Golecki for electron micrographs. The work was supported by the Deutsche Forschungsgemeinschaft.

\section{REFERENCES}

BenZ, R. \& BöHME, H. (1985). Pore formation by an outer membrane protein of the cyanobacterium Anabaena variabilis. Biochimica et biophysica acta 812 , 286-292.

BLIGH, E. G. \& DYER, W. J. (1959). A rapid method of total lipid extraction and purification. Canadian Journal of Biochemistry and Physiology 37, 911-917.

BRAUN, V.\& REHN, K. (1969). Chemical characterization, spatial distribution and function of a lipoprotein (murein-lipoprotein) of the Escherichia coli cell wall. European Journal of Biochemistry 10, 426-438.

DREWS, G. \& WeCKeSSER, J. (1982). Function, structure and composition of cell walls and external layers. In The Biology of Cyanobacteria, pp. 333-357. Edited by N. G. Carr and B. A. Whitton. Oxford: Blackwell Scientific Publications.

GaREWAL, H. S. (1973). A procedure for the estimation of microgram quantities of Triton X-100. Analytical Biochemistry 54, 319-324.

GoleckI, J. R. (1977). Studies on ultrastructure and composition of cell walls of the cyanobacterium Anacystis nidulans. Archives of Microbiology 114, 35-41.

JÜRgenS, U. J. \& WECKesSER, J. (1985). Carotenoidcontaining outer membrane of Synechocystis sp. strain PCC 6714. Journal of Bacteriology 164, 384-389.

JÜrgens, U. J. \& Weckesser, J. (1986). Polysaccharide covalently linked to the peptidoglycan of Synechocystis sp. strain PCC 6714. Journal of Bacteriology 168, 568-573.

JÜrgens, U. J., Drews, G. \& Weckesser, J. (1983). Primary structure of the peptidoglycan of the cyanobacterium Synechocystis sp. strain PCC 6714. Journal of Bacteriology 154, 471-478.

JÜRGENS, U. J., GoleCKI, J. R. \& WeCKesSER, J. (1985). Characterization of the cell wall of the unicellular cyanobacterium Synechocystis PCC 6714. Archives of Microbiology 142, 168-174.

LOWRY, O. H., ROBERTS, N. R., LEINER, K. Y., WU, M. L. \& FARR, A. L. (1954). The quantitative histochemistry of brain. I. Chemical methods. Journal of Biological Chemistry 207, 1-17.

MACKINNEY, G. (1941). Absorption of light by chlorophyll solutions. Journal of Biological Chemistry 140 , 315-322. murata, N., Sato, N., Omata, T. \& Kuwabra, T. (1981). Separation and characterization of thylakoid and cell envelope of the blue-green alga (cyanobacterium) Anacystis nidulans. Plant Cell Physiology 22, 855-866.

Omata, T. \& Murata, N. (1984). Isolation and characterization of three types of membranes from the cyanobacterium (blue-green alga) Synechocystis PCC 6714. Archives of Microbiology 139, 113-116.

Raziuddin, S., Siegelman, H. \& Tornabene, T. G. (1983). Lipopolysaccharides of the cyanobacterium Microcystis aeruginosa. European Journal of Biochemistry 137, 333-336.

Resch, C. M. \& Gibson, J. (1983). Isolation of the carotenoid-containing cell wall of three unicellular cyanobacteria. Journal of Bacteriology 155, 345 350 .

RipPKA, R., Deruelles, J., Waterbury, J. B., Herdman, M. \& Stanier, R. Y. (1979). Generic assignments, strain histories and properties of pure cultures of cyanobacteria. Journal of General Microbiology 111, 1-61.

SCHLeIfer, K. H. \& KandleR, O. (1972). Peptidoglycan types of bacterial cell walls and their taxonomic implications. Bacteriological Reviews 36, 407-477.

SCHMIDT, W., Drews, G., Weckesser, J., Fromme, I. \& Borowiak, D. (1980a). Characterization of the lipopolysaccharides from eight strains of the cyanobacterium Synechococcus. Archives of Microbiology 127, 209-215.

SChMidT, W., Drews, G., WeCKesser, J. \& MAyer, H. $(1980 \mathrm{~b})$. Lipopolysaccharides in four strains of the unicellular cyanobacterium Synechocystis. Archives of Microbiology 127, 217-222.

Schnaitman, C. A. (1971). Solubilization of the cytoplasmic membrane of Escherichia coli by Triton X-100. Journal of Bacteriology 108, 545-552.

Stransky, H. \& Hager, A. (1970). Das Carotinoidmuster und die Verbreitung des lichtinduzierten Xanthophylicyclus in verschiedenen Algenklassen. IV. Cyanophyceae und Rhodophyceae. Archiv für Mikrobiologie 72, 84-96.

WeCkesser, J., Drews, G. \& MaYer, H. (1979) Lipopolysaccharides of photosynthetic prokaryotes. Annual Review of Microbiology 33, 215-239. 